\title{
KETANGGUHAN MENTAL SISWA SMA NEGERI ATLET RAGUNAN JAKARTA
}

\author{
Risa Pratiwi \\ Ikhwan Lutfi \\ Ikatan Psikologi Sosial \\ ikhwan.lutfi@uinjkt.ac.id
}

\begin{abstract}
Mental toughness as a capability to last and solve any obstacles, difficulties, or pressure also stay focus in match becomes an important for an atlet. This research aimed to test the effect of motivation, coping strategy, and optimism toward mental toughness. Multiple regression test was conducted with 210 data sample of student atlet showed that all variable together have a significant effect. Independent variable"s dimensions which has a significant influence was positive thinking and hope.
\end{abstract}

Keywords: Mental Toughness, Coping Strategi, Optimism, Motivation

\begin{abstract}
Abstrak
Ketangguhan mental sebagai kesanggupan untuk bertahan dan mengatasi segala hambatan, kesulitan, atau tekanan serta tetap konsentrasi untuk bertanding menjadi hal yang sangat penting bagi atlet. Penelitian ini bertujuan untuk menguji pengaruh motivasi, strategi coping dan optimisme terhadap ketangguhan mental. Uji multiple regresi dilakukan dengan data 210 orang siswa sekolah atlet membuktikan bahwa secara bersama-sama ketiga variable memiliki pengaruh yang signifikan. Dimensi independen variable, yang memiliki pengaruh signifikan adalah berfikir positif dan harapan.
\end{abstract}

Kata Kunci: Ketangguhan Mental, Strategi Coping, Optimism, Motivasi

Diterima: 19 Agustus $2014 \quad$ Direvisi: 16 September 2014 Disetujui: 25 September 2014 


\section{PENDAHULUAN}

Ada beberapa faktor yang memiliki kontribusi atas prestasi seorang atlet, diantaranya adalah kondisi fisik (Alderman, 1947; James, 1982 ), skill (Alderman, 1947; ), dan psikologis (Alderman, 1947; Ogilvie, 1968; Cooper , 1969; Hardiman, 1973; James, 1982; Singgih, 1989). Dari faktor-faktor tersebut di atas, faktor mental/ketangguhan mental yang memiliki peran paling krusial untuk meningkatkan prestasi atlet seseorang (Meyers, Whelan, \& Murphy, 1996; Lidor \& Henschen, 2003; Andersen, 2005; Morris, Spittle, \& Watt, 2005; S. Murphy, 2005; Vealey, 2005; DeFrancesco \& Burke, 1997; Durand-Bush \& Salmela, 2002; Kitsantas \& Zimmerman, 2002).

Studi selama berpuluh-puluh tahun menunjukkan bahwa latihan mental pada atlet bukan hanya berfungsi untuk mencapai keberhasilan (prestasi) namun juga sekaligus penting bagi kesejahteraan pribadi (personal well-being) mereka (Meyers, Whelan, \& Murphy, 1996; Lidor \& Henschen, 2003; Andersen, 2005; Morris, Spittle, \& Watt, 2005; S. Murphy, 2005; Vealey, 2005). Sekurang-kurangnya minimal terdapat empat faktor penting yang harus dikembangkan guna melatih mental seorang atlet, yaitu ketrampilan dasar (foundation Skill), ketrampilan penampilan (performance skill), ketrampilan pengembangan diri (personal development skill), dan ketrampilan tim (team skill).

Atlet elit kelas internasional selalu memiliki kemampuan untuk kembali bangkit (resilience), kepercayaan diri dan keyakinan tak tergoyahkan (DeFrancesco \& Burke, 1997; Durand-Bush \& Salmela, 2002; Kitsantas \& Zimmerman, 2002). Artinya kepercayaan diri yang konsisten merupakan kunci keterampilan menuju mental tangguh (mental toughness)

Menurut Clough, Earl, dan Sewell (2002) ketangguhan mental adalah karakteristik individu yang cenderung mudah bergaul dan bersahabat memiliki rasa kepercayaan diri yang tinggi dan keyakinan yang tidak tergoyahkan, mampu mengendalikan nasib sendiri, orang-orang yang tetap relatif tidak terpengaruh oleh kompetisi atau kemalangan.

Batasan lain dikemukakan oleh Loehr (dalam Jones et al, 2005) yaitu kemampuan untuk merespon segala situasi dengan santai, tenang, dan berenergi karena atlet yang memiliki ketangguhan mental telah belajar untuk mengembangkan dua kemampuan. Pertama, kemampuan untuk meningkatkan energi positif dalam krisis dan kesulitan, dan kedua untuk berpikir dengan cara tertentu sehingga memiliki sikap yang tepat dalam menghadapi masalah, tekanan, kesalahan, dan persaingan.

Jones, Hanton, dan Connaughton (2007) menekankan bahwa ketangguhan mental sebagai sebuah kemampuan, dan merupakan sisi psikologis yang dimiliki secara alami atau yang dikembangkan oleh seseorang. Secara umum, ketangguhan mental dapat ditandai oleh kemampuan mengatasi tuntutan kompetisi, pelatihan dan gaya hidup 
dengan baik dari pada orang lain atau lawan bertanding dalam performa olahraga. Secara khusus, bertanding lebih konsisten, tetap fokus, percaya diri dan dapat memegang kendali di bawah tekanan dari pada lawan pada sisa waktu yang ditentukan.

Peneliti menggunakan batasan dari Gucciardi dkk (2008) sebagai pijakan berpikir. Pendapat ini menekankan bahwa ketangguan mental adalah kumpulan nilai-nilai, sikap, perilaku, dan emosi yang memungkinkan pemain untuk bertahan dan mengatasi segala hambatan, kesulitan, atau tekanan yang dialami, tetapi juga untuk menjaga konsentrasi dan motivasi mereka secara konsisten untuk mencapai tujuan.

Faktor-faktor yang dianalisa dalam penelitian untuk melihat ketangguhan mental atlet adalah motivasi, optimism, dan strategi coping. Motivasi memiliki peran yang penting atas munculnya ketangguhan mental seseorang. Hasil penelitian yang dilakukan oleh Omar et al (2012) mengkonfirmasi bahwa motivasi berperan kuat atas ketangguhan mental para pemain sepak bola Malaysia.

Strategi coping yang tepat memberikan kontribusi terhadap munculnya ketangguhan mental atlet (Jones, Graham, Sheldon, Hanton \& Connaughton, 2007; Nicholls et al, 2008 ). Nicholls et al (2008) mengatakan bahwa strategi coping (mental imagery, effort expenditure, thought control, dan logical analysis), tetapi tidak berkaitan dengan strategi coping penghindaran (distancing, mental distraction, dan resignation).

Optimisme secara konsisten sebagai karaketristik atlet yang dapat mempengaruhi ketangguhan Mental (Jones et al, 2002). Pada penelitian yang dilakukan Norlander dan Archer (dalam Nicholls, Polman, Levy \& Backhouse, 2007) ditemukan bahwa Optimisme adalah prediktor terbaik untuk ketangguhan mental dan performa atlet ski laki-laki dan perempuan antar negara dan perenang berusia 16-19 tahun. Optimisme digambarkan dalam psikologi positif baik sebagai harapan masa depan yang positif yang terbuka untuk pengembangan (Carver \& Scheier, 2002). De Rubeis, Evan, et al (dalam Parkes \& Mallett, 2011), mengatakan optimisme umumnya diukur sebagai harapan mengenai menghadapi kemungkinan hasil yang positif atau negatif.

Peneliti ingin mengetahui pengaruh variabel demografi diantaranya, jenis kelamin, usia, cabang olahraga, dan prestasi. Menurut Clough et al (dalam Nicholls et al, 2009) laki-laki lebih percaya diri dan memiliki mental yang lebih tinggi pada kemampuan dalam bertanding dibandingkan dengan perempuan. Penelitian yang dilakukan oleh Nicholls et al (2009) mengatakan jenis kelamin tidak mempengaruhi ketangguhan mental. Penelitian yang dilakukan oleh Nicholls et al (2009) menujukkan bahwa usia berkorelasi positif dengan ketangguhan mental. Usia yang muda dan tua memiliki perbedaan dalam self-perceptions, pengaruh sosial, respon emosional, motivasi dan self-regulation pada olahraga dan pengalaman berpartisipasi. Penelitian yang dilakukan oleh Bull, Shambrok, James dan 
Brooks (dalam Nicholls et al, 2009), mengatakan bahwa ketangguhan mental muncul pada olahraga tertentu. Hasil ini mengatakan atlet yang beregu, tidak beregu dan tipe olahraga yang berbeda-beda memiliki performa yang sama. Keduanya berpengaruh terhadap ketangguhan mental. Tetapi, pada penelitian Nicholls et al (2009) mengatakan bahwa tipe olahraga tidak berpengaruh terhadap ketangguhan mental. Prestasi dalam bertanding yang diperoleh oleh atlet dapat merubah atribut yang mendasari ketangguhan mental. Karena atlet dapat belajar dari pengalaman yang telah dialaminya. Connaughton et al (2008) mengatakan pengalaman kompetisi adalah faktor krusial dalam membangun ketangguhan mental antara atlet.

Penelitian ini dilakukan dengan tujuan untuk mendapatkan pemahaman yang lebih jelas dari pengaruh motivasi, strategi coping dan optimisme terhadap ketangguhan mental pada atlet. Penelitian dilakukan terhadap siswa atlet SMA Negeri Ragunan sebagai generasi mendatang dari atlet-atlet Indonesia. Di pundak merekalah presetasi olah raga Indonesia di masa datang diletakkan. Oleh karena itu penting mengidentifikasi kondisi ketangguhan mental dan factor yang mempengaruhi pada siswa sekolah ini.

\section{METODE}

Penelitian ini dilakukan pada atlet di SMA Negeri Atlet Ragunan Jakarta berjumlah 250 orang. Pengambilan data dilakukan pada seluruh populasi, tetapi yang mengembalikan berjumlah 230 orang.

Instrumen pengambilan data menggunakan adaptasi dari skala ketangguhan mental Mental Toughness Questionnaire 48 (MTQ48) yang terdiri dari empat aspek menurut Clough et al (2002) yaitu control, commitment, challenge dan confidence. Dari 48 item pada alat ukur MTQ48 hanya 27 item yang digunakan untuk menyesuaikan kebutuhan penelitian ini.

Skala motivasi menggunakan The Multi-Motive Grid (MMG) dari Schmalt dan Sokolowski (1992) yang terdiri dari 12 item. Pengambilan data strategi coping berdasar pada Inventaire des Strate'gies de Coping en Compe'tition Sportive (ISCC), yang kemudian diadaptasi menjadi Coping Strategies in Sport Competition Inventory oleh Clark, Watson dan DeVellis (1995) dan terdiri dari 39 item dengan dua aspek yaitu task-oriented coping dan emotion-oriented.

Uji validitas item dengan Confirmatory Factor Analysis (CFA) menghasilkan 20 item MTQ48 yang valid, dari skala The Multi-Motive Grid (MMG) diperoleh 11 item yang valid, Coping Strategies in Sport Competition Inventory diperoleh 33 item yang valid, dan Life Orientation Test-Resived (LOT) diperoleh 8 item yang valid.

Skala optimisme pada penelitian ini mengadopsi alat ukur Life Orientation Test-Revised. Life Orientation Test-Revised yang dipublikasikan oleh Scheir dan Carver (1994). Life Orientation Test awalnya dipublikasikan pada tahun 1985 tetapi Scheir dan Carver mengevaluasi alat ukur ini kembali pada tahun 1994. Life Orientation Test-Resived (LOT) terdiri dari 10 item. 
Peneliti melakukan exploratory analysis pada skala optimisme untuk melihat dimensi yang terbentuk dari sepuluh item pada skala optimisme. Ada dua dimensi yang terbentuk lalu peneliti menamai dimensi tersebut berdasarkan kelompok item yang terkumpul pada masing-masing dimensi sesuai dengan definisi optimisme. Dimensi tersebut diberi nama berfikir positif dan harapan karena menurut Carver dan Scheier (2002) individu yang lebih optimis digambarkan memiliki harapan dan selalu berfikir positif.

\section{Gambaran Subyek Penelitian}

Penelitian ini dilakukan di SMAN Atlet Ragunan Jakarta dengan subyek penelitian 230 atlet. Berikut ini gambaran umum mengenai subyek penelitian berdasarkan jenis kelamin, usia, asal daerah, cabang olahraga, dan prestasi.

\section{Responden Berdasarkan Jenis Kelamin}

Peneliti akan memaparkan distribusi populasi berdasarkan jenis kelamin, yaitu sebagaimana yang tertera pada tabel di bawah ini

\section{Tabel 1}

Distribusi Responden Berdasarkan Jenis Kelamin

\begin{tabular}{lll}
\hline Jenis Kelamin & Frequency & Percent \\
\hline Perempuan & 105 & $45,7 \%$ \\
Laki-laki & 125 & $54,3 \%$ \\
\hline
\end{tabular}

Tabel di atas menunjukkan bahwa responden penelitian secara umum didominasi oleh atlet laki-laki dengan perbandingan prosentase adalah $54,3 \%$ (125 orang) untuk laki2 dan 45,7\% (105 orang) untuk atlet perempuan.

\section{Responden Berdasarkan Cabang Olahraga}

Gambaran umum responden berdasarkan cabang olahraga dijelaskan pada tabel berikut.

\section{Tabel 2}

Distribusi Responden Berdasarkan Cabang Olahraga

\begin{tabular}{lll}
\hline Cabang Olahraga & Frequency & Percent \\
\hline Atletik & 53 & $23 \%$ \\
Bela Diri & 48 & $20,9 \%$ \\
Permainan Bola & 129 & $56,1 \%$ \\
\hline Total & $\mathbf{2 3 0}$ & $\mathbf{1 0 0} \%$ \\
\hline
\end{tabular}

Dari tabel 2 dapat dilihat bahwa cabang olahraga dikelompokkan menjadi 3 kelompok yaitu 23\% (53 orang) berasal dari cabang olahraga atletik, 20,9\% (48 orang) berasal cabang olahraga bela diri seperti yudo, 
taekwondo, tinju d1l, 56,1\% (129 orang) berasal dari cabang olahraga permainan bola seperti sepak bola, bulu tangkis, tenis, basket, sepak takraw dll.

\section{Skor Variabel Kontinum}

Berikut ini adalah hasil penghitungan kategorisasi skor variable-variabel yang datanya kontinum, yaiut ketangguhan mental dan optimisme.

\section{Tabel 3}

Kategorisasi Variabel

\begin{tabular}{lcc}
\hline Variabel & Rendah & Tinggi \\
\hline Ketangguhan mental & 123 & 107 \\
& $53.5 \%$ & $46.5 \%$ \\
\hline Optimisme (berpikir positif) & 83 & 147 \\
& $36.1 \%$ & $63.9 \%$ \\
\hline Optimisme (harapan) & 106 & 124 \\
& $(46.1 \%)$ & $(53.9 \%)$ \\
\hline
\end{tabular}

Berdasarkan tabel 3 diketahui bahwa responden yang memiliki tingkat ketangguhan mental rendah adalah 123 orang dengan persentase sebesar $46,5 \%$, sedangkan responden yang memiliki ketangguhan mental tinggi berjumlah 107 orang atau sebesar 53,5\%. Kondisi ini mengindikasikan bahwa kebanyakan responden dalam penelitian ini memiliki ketangguhan mental yang rendah.

Masih berdasarkan tabel 3 diketahui bahwa responden yang memiliki tingkat optimisme (berfikir positif) rendah dengan persentase sebesar 36,1\% atau sebanyak 83 orang, sedangkan responden yang memiliki optimisme (berfikir positif) tinggi sebanyak 147 orang atau sebesar 63.9\%. Keadaan ini menunjukkan bahwa kecenderungan berpikir responden dikuasai oleh mereka yang memiliki pikiran positif dibandingkan yang berpikir negatif.

Dimensi optimism yang kedua adalah tentang harapan. Table ini di atas dapat dibaca bahwa jumlah responden yang memiliki harapan tinggi lebih dominan dibandingkan yang memiliki harapan rendah, yaitu 124 orang $(53,9 \%)$ dibandingkan dengan 106 orang $(46,1 \%)$. Hal ini mengindikasikan, bahwa siswa sekolah atlet Ragunan memiliki optimisme yang tinggi baik dari sisi berpikir positif maupun dari dimensi yang lain, yaitu harapan.

\section{Motivasi}

Berikut ini adalah hasil penghitungan kategorisasi skor motivasi. 


\section{Tabel 4}

Hasil Kategorisasi Skor Motivasi

\begin{tabular}{lll}
\hline & Frequency & Percent \\
\hline Kebutuhan Berafiliasi & 97 & 35.2 \\
Kebutuhan Berprestasi & 52 & 22.6 \\
Kebutuhan Kekuasaan & 81 & 35.2 \\
\hline Total & 230 & 100 \\
\hline
\end{tabular}

Berdasarkan tabel 4 diketahui bahwa responden yang memiliki motivasi (kebutuhan berafiliasi) sebanyak 97 orang dengan presentasi 35,3 $\%$, responden yang memiliki motivasi (kebutuhan berprestasi) sebanyak 52 orang dengan presentasi $22,6 \%$, sedangkan responden yang memiliki motivasi (kebutuhan akan kekuasaan) sebanyak 81 orang dengan presentasi $35,2 \%$.

Data dari tabel di atas menunjukkan bahwa motivasi yang dominan dari siswa atlet ragunan adalah afiliasi, kemudian diikuti kekuasaan dan terakhir prestasi. Kondisi ini berarti orientasi para atlet ternyata lebih menunjukkan kecenderungan untuk mengembangkan sosialisasi dan mencari teman dibandingkan kebutuhan-kebutuhan yang lain. Kebutuhan kedua adalah kebutuhan untuk berkuasa dapat dikategorikan lebih dominan dibandingkan kebutuhan prestasi.

Kondisi ini menjadi sangat ironis, terlebih bila melihat latar belakang responden penelitian, yaitu siwa sekolah atlet. Secara common sense, motivasi yang seharusnya menonjol dan dominan dari para atlet adalah kebutuhan untuk berprestasi. Tetapi kondisi yang melekat pada responden justru menunjukkan kondisi sebaliknya. Kebutuhan untuk prestos hanya dimiliki oleh sebagian kecil siswa, secara prosentase adalah $22.6 \%$ (52 orang).

\section{Strategi Coping}

Berikut ini adalah hasil penghitungan kategorisasi skor Strategi Coping.

\section{Tabel 5}

Hasil Kategorisasi Skor Strategi Coping

\begin{tabular}{lll}
\hline & Frequency & Percent \\
\hline Task-oriented Coping & 107 & 46.5 \\
Emotion-oriented Coping & 123 & 53.5 \\
Total & 230 & 100 \\
\hline
\end{tabular}

Berdasarkan tabel 5 diketahui bahwa responden yang memiliki strategi coping yang berorientasi pada task sebanyak 107 orang dengan presentasi 46,5\%, sedangkan responden yang memiliki strategi coping yang berorientasi pada emotion sebanyak 123 orang dengan presentasi 53,5\%. Hal ini berarti bahwa dominasi penyelesaian masalah dari para siswa 
sekolah atlet adalah emosional focus. Artinya ketika muncul masalah dan persoalan, pendekatan yang lebih banyak digunakan adalah berorientasi pada emosi. Artinya persoalan yang muncul akan di atasi dengan mengutamakan kesejahteraan psikologis, dan bukan pada masalah itu sendiri. Hal ini tentunya tidak sesuai dengan kondisi ideal, atau pendekatan penyelesaian masalah yang seharusnya dimiliki.

Task oriented coping bertolak belakang dalam mendekati ataupun mengatasi masalah dengan emotion coping. Task coping memfokuskan diri pada bagaimana masalah itu muncul, mengapa muncul dan bagaimana mengatasinya. Strategi-strategi apa yang akan dipilih dalam mengatasi persoalan yang mucul. Task coping akan memunculkan perilaku seperti identifikasi permaslahan, pedekatan baru, dan rencana konkret atas masalah tersebut. Langkah konkret yang akan ditempuh oleh pemilik tas coping adalah bagaiman meningkatkan kemampun sehingga bias menyelesaikan hambatan dalam berlatih dan bertanding.

Strategi coping ini ternyata konfirmasi dengan motivasi yang dimiliki oleh responden. Sebagian besar responden memiliki kebutuhan berafiliasi, hal ini menjadi masuk akal bila kemudian strategi coping yang digunakan adalah emosi coping .

\section{Uji Hipotesi Penelitian}

Uji hipotesis dilakukan dengan menggunakan teknik regresi berganda dengan menggunakan software SPSS 17. Analisa pertama dilakukan untuk melihat besaran $\mathrm{R}$ square atau prosentase varians dari dependent variable, yaitu ketangguhan mental yang diprediksikan oleh keseluruhan independent variable, sebagaimana table 6 di bawah ini.

Tabel 6

Model Summary

\begin{tabular}{cccl}
\hline $\mathbf{R}$ & R Square & Adjusted R Square & $\begin{array}{l}\text { Std. Error of The } \\
\text { estimate }\end{array}$ \\
\hline $1.608^{\mathrm{a}}$ & .370 & .335 & 7.46178 \\
\hline
\end{tabular}

a. Predictors: (Constant), MOTIV, COPING, POSITIF, HOPE, USIA, JK, CO, PRES

b. Dependent Variable: MT

Sebagaimana tabel di atas, terlihat bahwa $37 \%$ bervariasinya ketangguhan mental ditentukan oleh bervariasinya independent variable yang diteliti. Sedangkan $63 \%$ sisanya dipengaruhi oleh variabel lain diluar penelitian.

Analisis pengaruh dari keseluruhan independent variable pada penelitian ini terhadap ketangguhan mental. Adapun uji $\mathrm{F}$ dapat dilihat pada tabel 7 berikut ini. 
Tabel 7

Tabel Anova

\begin{tabular}{ccccccc}
\hline & Model & $\begin{array}{c}\text { Sum of } \\
\text { Squares }\end{array}$ & Df & $\begin{array}{c}\text { Mean } \\
\text { Square }\end{array}$ & F & Sig \\
\hline 1 & Regression & 7093.232 & 12 & 591.103 & 10.616 & $.000^{\mathrm{a}}$ \\
& Residual & 12082.151 & 217 & 55.678 & & \\
\hline & Total & 19175.383 & 229 & & & \\
\hline
\end{tabular}

a. Predictors: (Constant), MOTIV, COPING, POSITIF, HOPE, USIA, JK, CO, PRES

b. Dependent Variable: MT

Dari tabel di atas, terlihat bahwa nilai signifikansi pada kolom paling kanan adalah $(\mathrm{p}<0,05)$, maka hipotesis penelitian diterima, yaitu terdapat pengaruh yang signifikan dari motivasi, strategi coping, optimisme (berfikir positif), optimisme (harapan) dan juga variabel demografi terhadap ketangguhan mental.

Analisis selanjutnya adalah mencari koefisien regresi dari seluruh dimensi independent variable. Sebagaimana tergambar dalam tabel di bawah 8 ini:

\section{Tabel 8}

Koefisien Regresi

\begin{tabular}{|c|c|c|c|c|c|}
\hline \multirow{2}{*}{ Model } & \multicolumn{2}{|c|}{$\begin{array}{c}\text { Unstandardized } \\
\text { Coefficients }\end{array}$} & \multirow{2}{*}{$\begin{array}{c}\begin{array}{c}\text { Standardized } \\
\text { Coefficients }\end{array} \\
\text { Beta }\end{array}$} & \multirow[t]{2}{*}{$T$} & \multirow[t]{2}{*}{ Sig. } \\
\hline & B & $\begin{array}{l}\text { Std. } \\
\text { Error }\end{array}$ & & & \\
\hline (Constant) & 6.193 & 11.017 & & .562 & .575 \\
\hline MOTIV & .649 & 1.369 & .022 & .353 & .672 \\
\hline COPING & -1.167 & 1.088 & -.064 & -1.073 & .284 \\
\hline POSITIF & .499 & .065 & .241 & 4.087 & .000 \\
\hline HOPE & .009 & .070 & .441 & 7.171 & .000 \\
\hline JK & .277 & 1.082 & .000 & -.008 & .993 \\
\hline USIA & 2.656 & .584 & .029 & .475 & .635 \\
\hline $\mathrm{CO}$ & -1.326 & 1.561 & .211 & 3.044 & .271 \\
\hline PRES & -.252 & 1.794 & .267 & -.303 & 1.629 \\
\hline
\end{tabular}

b. Dependent Variable : MT

Berdasarkan koefisien regresi pada tabel 8 dapat disampaikan persamaan regresi sebagai berikut:

Ketangguhan Mental ${ }^{`}=6,193+0,649$ (motivasi) $+(-1.167)$ coping $+0,499$ (positif)* $^{*} 0,009$ (harapan)* $+0,277$ (jenis kelamin $)+(2,656)$ usia $+(-1,326)$ cabang olahraga $+(-0,252)$ prestasi 
Dari tabel di atas, untuk melihat signifikan atau tidaknya koefisien regresi yang dihasilkan, kita cukup melihat nilai Sig pada kolom yang paling kanan (kolom ke-6), jika $\mathrm{P}<0.05$, maka koefisien regresi yang dihasilkan signifikan pengaruhnya terhadap ketangguhan mental dan sebaliknya. Dari hasil diatas, hanya koefisien optimisme (berfikir positif) dan optimisme (harapan) yang signifikan, sedangkan lainnya tidak. Hal ini berarti bahwa dari 8 hipotesis minor terdapat 2 yang signifikan. Penjelasan dari nilai koefisien regresi yang diperoleh masing-masing IV adalah sebagai berikut:

1. Nilai koefisien regresi motivasi sebesar $+0,649$ dengan signifikansinya sebesar 0,672 ( $\mathrm{p}>0,05)$. Hal ini berarti variabel motivasi tidak berpengaruh signifikan terhadap ketangguhan mental.

2. Nilai koefisien regresi strategi coping sebesar $-1,167$ dengan signifikasinya sebesar 0,284 $(\mathrm{p}>0,05)$. Hal ini berarti variabel strategi coping tidak berpengaruh signifikan terhadap ketangguhan mental.

3. Nilai koefisien regresi optimisme (berfikir positif) sebesar $+0,499$ dengan signifikasinya sebesar $0,000(p<0,05)$. Hal ini berarti variabel optimisme (berfikir positif) secara positif berpengaruh signifikan terhadap ketangguhan mental. Artinya semakin positif pikiran seseorang maka semakin tanggung mentalnya. Dan sebalikinya, semakin berpikir negative maka mentalnya akan semakin rapuh.

4. Nilai koefisien regresi optimisme (harapan) sebesar $+0,009$ dengan signifikasinya sebesar $0,000(p<0,05)$. Hal ini berarti variabel optimisme (harapan) secara positif berpengaruh signifikan terhadap ketangguhan mental. Artinya semakin tinggi harapan seseorang maka semakin tinggi pula ketangguhan mentalnya. Semakin rendah harapan seorang atlet, maka mental yang dimilikinya semakin tidak tangguh/rapuh.

5. Nilai koefisien regresi jenis kelamin sebesar $+0,277$ dengan signifikasinya sebesar 0,993 ( $p>0,05)$. Hal ini berarti variabel jenis kelamin tidak berpengaruh signifikan terhadap ketangguhan mental.

6. Nilai koefisien regresi usia sebesar $+2,656$ dengan signifikasinya sebesar $0,635$ ( $p>0,05)$. Hal ini berarti variabel usia tidak berpengaruh signifikan terhadap ketangguhan mental.

7. Nilai cabang olahraga koefisien regresi sebesar $-1,326$ dengan signifikasinya sebesar $0,271(\mathrm{p}>0,05)$. Hal ini berarti variabel cabang olahraga tidak berpengaruh signifikan terhadap ketangguhan mental.

8. Nilai koefisien regresi prestasi sebesar $-0,252$ dengan signifikasinya sebesar 1,629 ( $p>0,05)$. Hal ini berarti prestasi tidak berpengaruh signifikan terhadap ketangguhan mental.

Dari delapan independent variable yang diteliti, hanya dua independent variable yang berpengaruh signifikan terhadap ketangguhan mental. Setelah melakukan penelitian, diketahui independent variable yang signifikan berpengaruh yaitu optimisme (berfikir positif) dan optimisme (harapan). 
Variabel motivasi, strategi coping, jenis kelamin, usia, cabang olahraga dan prestasi tidak berpengaruh secara signifikan terhadap ketangguhan mental.

Hasil penelitian menunjukan bahwa variabel optimisme (berfikir positif) memiliki pengaruh yang signifikan terhadap ketangguhan mental secara positif. Variabel optimisme (berfikir positif) signifikan baik pada pengujian koefisien regresi maupun proporsi variansnya. Hasil ini sejalan dengan penelitian yang dilakukan oleh Nicholls et al (2008), optimisme ditemukan memiliki pengaruh sedang sampai tinggi terhadap ketangguhan mental (challenge, komitmen, control emotion, life control, confidence in ability, dan interpersonal confidence). Korelasi negatif ditemukan untuk ketangguhan mental dengan pesimisme.

Peneliti menyimpulkan jika atlet memiliki optimisme yang tinggi dengan selalu berfikir positif pada segala situasi khususnya saat bertanding maka akan memunculkan ketangguhan mental yang tinggi. Variabel optimisme (berfikir positif) juga memberikan sumbangan cukup besar pada penelitian ini.

Untuk hasil penelitian mengenai pengaruh variabel optimisme (harapan) memiliki pengaruh yang signifikan terhadap ketangguhan mental secara positif. Variabel optimisme (harapan) signifikan baik pada pengujian koefisien regresi maupun proporsi variansnya. Pada penelitian ini variabel optimisme (harapan) memiliki pengaruh yang paling tinggi diantara variabel independent lainnya.

Hasil ini sejalan dengan penelitian yang dilakukan oleh Nicholls et al (2008), optimisme ditemukan memiliki pengaruh sedang sampai tinggi terhadap ketangguhan mental (challenge, komitmen, control emotion, life control, confidence in ability, dan interpersonal confidence). Korelasi negatif ditemukan untuk ketangguhan mental dengan pesimisme.

Peneliti menyimpulkan jika atlet selalu optimis dan selalu memiliki harapan yang tinggi saat berada pada situasi sulit pada pertandingan olahraga maka akan memunculkan ketangguhan mental yang tinggi. Variabel optimisme (harapan) juga memberikan sumbangan paling besar pada penelitian ini.

Variabel motivasi tidak signifikan pengaruhnya terhadap ketangguhan mental. Variabel motivasi tidak signifikan pada pengujian koefisien regresi tetapi signifikan proporsi variansnya. Atlet yang memiliki kebutuhan berprestasi, kebutuhan berafiliasi maupun kebutuhan kekuasaan tidak signifikan mempengaruhi ketangguhan mental. Hal ini tidak sejalan dengan hasil penelitian Omar et al (2012) yang menunjukkan motivasi mempengaruhi ketangguhan mental pada performa baik pada mantan atlet sepak bola maupun tim sepak bola Malaysia. Hasil penelitian ini juga tidak sejalan dengan penelitian yang dilakukan Shojaei et al, 2007 (dalam Omar et al, 2012).

Peneliti menyimpulkan atlet yang memiliki kebutuhan berprestasi, kebutuhan berafiliasi maupun kebutuhan kekuasaan pada situasi olahraga 
maupun saat bertanding tidak mempengaruhi atlet tersebut memiliki ketangguhan mental yang tinggi pula. Penelitian ini tidak sejalan dengan penelitian Omar et al (2012) mungkin disebabkan oleh perbedaan budaya di Indonesia dengan penelitian yang dilakukan Omar et al (2012) di Malaysia. Perbedaan pendekatan penelitian yang digunakan Omar et al dengan pendekatan kualitatif sedangkan penelitian ini menggunakan pendekatan kuntitatif. Responden yang diteliti hanya atlet sepak bola sedangkan penelitian ini meneliti atlet dari cabang olahraga yang bermacam-macam seperi atletik, basket, sepak bola, silat, yudo dan lain-lain.

Variabel strategi coping tidak signifikan pengaruhnya pada pengujian koefisien regresi, namun signifikan pada pengujian proporsi varians. Penelitian ini tidak sejalan dengan penelitian yang dilakukan oleh Nicholls et al (2008) yang mengatakan strategi coping secara signifikan berkorelasi dengan ketangguhan mental. Artinya, pada atlet yang memiliki ketangguhan mental yang tinggi lebih dikaitkan dengan pendekatan strategi coping yang berorientasi pada tugas (mental imagery, effort expenditure, thought control, dan logical analysis), tetapi tidak berkaitan dengan strategi coping menghindar (distancing, mental distraction, dan resignation).

Selanjutnya untuk variabel demografi, variabel demografi seperti jenis kelamin, usia, cabang olahraga dan prestasi tidak ada satupun yang signifikan pada pengujian koefisien regresi dan proporsi variansnya. Variabel jenis kelamin tidak signifikan mempengaruhi ketangguhan mental. Hal ini tidak sejalan dengan hasil penelitian yang dilakukan oleh Clough et al (dalam Nicholls, 2009) Laki-laki secara signifikan memiliki skor total ketangguhan mental lebih tinggi daripada perempuan. Tetapi hal ini sejalan dengan penelitian Nicholls (2009) yang mengatakan jenis kelamin tidak signifikan. Perbedaan ini bisa disebabkan oleh variasi atribut yang mendasari yang berhubungan dengan ketangguhan mental pada laki-laki dan perempuan atau sebaliknya atau proses sosialisasi antara perempuan dan laki-laki yang berbeda.

Pada penelitian ini jenis kelamin tidak signifikan mempengaruhi ketangguhan mental. Hal ini membuktikan bahwa di Indonesia jenis kelamin tidak mempengaruhi ketangguhan mental. Hal ini tidak sejalan dengan penelitian Clough (dalam Nicholls et al, 2009) yang dilakukan di Amerika yang mengatakan bahwa jenis kelamin signifikan.

Variabel usia juga tidak signifikan mempengaruhi ketangguhan mental pada pengujian koefisien regresi maupun proporsi varians. Hal ini tidak sejalan dengan penelitian yang dilakukan oleh Nicholls et al (2009) karena penelitian ini mengatakan ada pengaruh usia terhadap ketangguhan mental.

Pada penelitian ini usia tidak signifikan mempengaruhi ketangguhan mental. Hal ini sejalan dengan penelitian Nicholls et al (2009) yang dilakukan di Amerika yang mengatakan bahwa usia tidak signifikan pula. Penelitian pada sampel atlet Indonesia khususnya di SMAN Atlet Ragunan 
Jakarta dan di Amerika mengenai usia tidak mempengaruhi ketangguhan mental.

Variabel cabang olahraga juga tidak signifkan berpengaruh terhadap ketangguhan mental baik koefisien regresinya maupun proporsi varians. Hal ini sejalan dengan hasil penelitian yang dilakukan oleh Nicholls et al (2009) yang menunjukkan bahwa tidak ada perbedaan yang signifikan di antara atlet yang berpartisipasi dalam tim atau olahraga individu dan atlet yang berpartisipasi dalam kontak atau non-kontak olahraga dan juga jenis olahraga atlet terhadap ketangguhan mental. Temuan ini mendukung gagasan bahwa ketangguhan mental adalah sifat kepribadian yang tidak berbeda dari situasi ke situasi, seperti yang disarankan oleh Bull et al (2005).

Pada penelitian ini cabang olahraga tidak signifikan mempengaruhi ketangguhan mental. Hal ini sejalan dengan penelitian Nicholls et al (2009) yang dilakukan di Amerika yang mengatakan bahwa cabang olahraga tidak signifikan pula. Hal ini membuktikan bahwa cabang olahraga tidak mempengaruhi ketangguhan mental di Amerika maupun di Indonesia khususnya di SMAN Atlet Ragunan Jakarta.

Selanjutnya, untuk hasil penelitian mengenai pengaruh variabel prestasi tidak signifikan berpengaruh terhadap ketangguhan mental baik koefisien regresinya maupun proporsi varians. Hal ini sejalan dengan hasil penelitian yang dilakukan oleh Nicholls et al (2009), atlet yang memiliki tingkat prestasi tinggi tidak berpengaruh pada ketangguhan mental. Hal ini tidak sejalan dengan hasil penelitian Golby dan Sheed (dalam Nicholls at al, 2009) atlet yang tingkat prestasinya lebih tinggi memiliki atribut fisik dan kemampuan teknis yang lebih akurat dibandingkan dengan atlet yang memiliki tingkat prestasi lebih rendah.

Pada penelitian ini prestasi tidak signifikan mempengaruhi ketangguhan mental. Hal ini sejalan dengan penelitian Nicholls et al (2009) yang dilakukan di Amerika yang mengatakan bahwa prestasi tidak signifikan pula. Hal ini membuktikan bahwa atlet yang memiliki prestasi sedikit atau banyak tidak mempengaruhi ketangguhan mental di Amerika maupun di Indonesia khususnya di SMAN Atlet Ragunan Jakarta.

Berdasarkan hasil penelitian dan dikusi, rekomendasi yang dapat diberikan adalah peningkatan ketangguhan mental difokuskna pada latihan imagery terutama untuk penguatan optimism. Pemahaman akan kemampuan dan kepercayaan diri mutlak bagi atlet Indonesia. Pendampingan oleh ahli penguatan mental menjadi rekomendasi berikutnya. 


\section{DAFTAR PUSTAKA}

B, James, Avey, Rebecca J. Reichard, Fred Luthans, Ketan H. Mhatre. (2011). - Meta analysis of the impact of positive psychological capital on employee attitudes, behaviors, and performancell. Journal Human Resource Development Quarterly, 22, (2), 127-152.

BBC (2013). Keberhasilan tim U-19 menjuarai AFF 2013. Diunduh pada tanggal 22 Agustus 2014, dari http://www.bbc.co.uk/indonesia/laporan_khusus /2013/11/131107_tokoh_indra_sjafri.shtml

Budiastuti, Zulfa (2012). Pengaruh motivasi dan persepsi budaya organisasi terhadap perilaku kerja kontraproduktif pada pegawai negeri sipil kementrian Agama Republik Indonesia. Jakarta : Universitas Islam Negeri Syarif Hidayatullah Jakarta.

Clough, Peter. Earle, Keith dan Crush, Lee. (2002). - The design and development of the MTQ48I. Journal The Sport Psychologist, 22, (1) 120.

Connaughton, Declan and Sheldon Hanton. (2010).-The development and maintenance of mental toughness in the world's best performersll. Journal The Sport Psychologist, 24, 168-193.

Crust, Lee and Ian Lawrence. (2006), -Leadership preferences of mentally tough athletesll, Journal of Sport Psychology, 15, (2) 1-22.

Crust, Lee and Kayvon Azadi. (2006), - Mental toughness and athletes' use of psychological strategiesll, Journal of Sport Psychology, 12, (2), 22-32.

Fisher, A.C. (1976). Phychology of Sport. Palo Alto: Mayfiel Publ. Co Folkman, Lazarus, Rand J. Susan, Richard S. Gruen, dan Anita DeLongis. (1986). - Appraisal, coping, health status, and psychological symptomsll. Journal of Personality and Social Psychology, 50, (3), 571579.

Gaudreau, P and Blondin, J.P.(2002), -Development of a questionnaire for the assessment of coping strategies employed by athletes in competitive sport settings ll, Psychology of Sport and Exercise, (3), 1-34.

Gucciardi, Daniel F dan Jones, Martin. (2012). -Beyond optimal performance: mental toughness profiles and developmental success in adolescent cricketersll. Journal of Sport \& Exercise Psychology, (34), 1636.

Jones, Graham and Adrian Moorhouse. (2008). Developing mental toughness, for transforming your business performance. UK: gold medal strategies

British Library.

Jones, Graham, Sheldon Hanto and Declan Connaughton. (2005), -What is this thing called mental toughness? an investigation of elite sport performersll, Journal of Applied Sport Psychology, (14), 205-218. 
Jones, Graham, Sheldon, Hanto dan Declan Connaughton. (2007), "Framework of mental toughness in the world's best performersll, The Sport Psychologist. (21), 243-264.

Jones, Parker .(2013) - What is the size of the relationship between global mental toughness and youth experiences?\|I Personality and Individual Differences, (54), 519-523.

Levy, Andrew R. Remco C.J. Polman, Peter J. Clough, David C. Marchant, dan Keith Earle. (2006). - Mental toughness as a determinant of beliefs, pain, and adherence in sport injury rehabilitationll. J Sport Rehabil, (15), 246-254.

Luthans, Fred. James B. Avey, Bruce J. Avolio, Suzanne J. Peterson. (2011). - The Development and resulting performance impact of positive psychological capitall. Journal Human Resource Development Quarterly, (22), 2.

Nicholls, Adam R, Polman, Remco C.J Levy, Andrew. R, Backhous, Susan. H. (2008). - Mental toughness, optimism, pessimism, and coping among athletesll, Personality and Individual Differences, (44), 1182-1192.

Nicholls, Pollman, Andrew. (2009) - Toughness in sport: Achievement level, gender, age, experience, and sport type differencesll. Personality and Individual Differences, 47, (6), 73-75.

Omar-Fauzee, M.S and Yudha H. Saputra. (2012), - Mental toughness among footballers: a case studyll, International Journal of Academic Research in Business and Social Sciences, 1, (2), 2222-6990.

Parkes, Jarred F, Mallett, Clifford J. (2011).-Developing mental toughness: attributional style retraining in rugby .II The Sport Psychologist, (25), 269-287.

Santacana, Maria, Teresa Kirchner, Judit Abad, and Juan Antonio Amador. (2012). -Differences between genders in coping: different coping strategies or different stressors?ll. Anuario de Psicologia, 42, (1), $5-18$.

Scheier, Michael F. Carver, Charles S. Brissette, Ian. (2002). - The Role of optimism in social network development, coping, and psychological adjustment during a life transitionll. Journal of Personality and Social Psychology, 82,(1), 102-111.

Segerstrom, Suzanne.C, Taylor, Shelley. E, Kemeny, Margaret E, Fahey, John. L. (1998). -Optimism is associated with mood, coping, and immune change in response to stressll. Personality and Social Psychology, 74, (6), 1646-1655.

Sokolowski, Schmalt, Langens \& Puca, M. Rosa (2000). Assesing achievement, affilation, and power motives all at once: the multimotive grid (MMGI). Journal of Personality and Asessment, 74, (1), 126145. 
